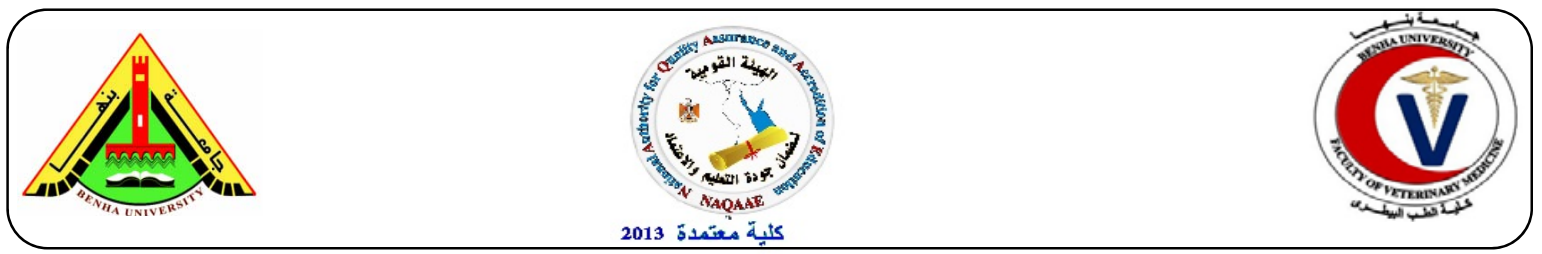

\title{
Protection of mice by oral vaccination with Brucella Melitensis vaccine (REV.1) in combination with flagellar protein against a virulent Brucella melitensis $16 \mathrm{M}$ strain
}

\author{
${ }^{1}$ Lubna F. Farahat, ${ }^{2}$ Mohamed G. Abdelwahab, ${ }^{2}$ Abdel-Moneim, Mustafa, ${ }^{2}$ Mohamed H. Ebied
} and ${ }^{1}$ Saleh, M.S. El-Ayouby

${ }^{1}$ Antigens and Serums Dep., VSVRI. Abbasia, Cairo Egypt. ${ }^{2}$ Animal Medicine Department, Faculty of veterinary Medicine, Benha University, Egypt.

\section{A B S T R A C T}

We evaluated orally administered live attenuated B. melitensis Rev.1 vaccine in combination with flagellin to protect mice against I/P challenge with Brucella melitensis $16 \mathrm{M}$ bacteria. Optimal protection was enhanced by three booster immunization doses against challenge at 3 weeks post challenge. Experiments were performed with mice to elucidate the roles of humoral and cell-mediated immune responses in the acquisition of protective immunity to Brucella melitensis and to compare infection immunity with immunity developed through vaccination with oral reduced dose of Rev.1 vaccine of $B$. melitensis combined with flagellar protein $\left(\mathrm{H}_{7}\right)$. Vaccination with reduced dose of Rev.1 vaccine orally combined with flagellar protein is better than the vaccination with full dose of Rev.1 vaccine $\mathrm{S} / \mathrm{C}$ in mice. From the results its pointed out that the cell mediated immunity elicited by the use of oral reduced dose of Rev.1 vaccine (3 Successive) dose combined with flagellar protein.

Key words: Brucella Melitensis, flagellar protein, vaccine

\section{INTRODUCTION}

$\mathrm{B}$ rucellosis is a serious zoonotic disease caused by different species of genus Brucella characterized by infertility and abortion in animals and a febrile illness (undulant fever) in humans (Corbel et al.,1997). The disease exists worldwide, especially in Central and South America, India, the Mediterranean basin, the Middle East, and continues to have great health significance and economic importance in these areas (Boschiroli et al., 2001). In areas where it is endemic, human brucellosis is quite common but often not diagnosed (Marin et al., 1999) (Zvizdic et al., 2006). At present, the live attenuated Brucella melitensis Rev.1 strain developed by (Elberg S.S.1981) is still the only vaccine employed for controlling the caprine brucellosis, as (Scharp et al.1999) mentioned It has been also useful for the control and eradication of this disease. So that, it was used in comprehensive vaccination programs in many countries, including Syria, Saudi-Arabia, Kuwait, Mongolia, Spain, and Turkey (Refai 2002). However, there are several problems associated with its use in animals. The first issue lies within the fact that Rev. 1 contains OPS similar to field strains of B. melitensis and vaccination with this strain leads to the production and persistence of OPS- specific antibodies (Blasco1997). It may induce abortions in pregnant goats (Alton 1987). Produces persistent infections, and is excreted in milk during two or more lactations. In order to avoid these drawbacks, alternative vaccination approaches are needed. Live attenuated Brucella vaccines have been available for protection domestic livestock against $B$. 
melitensis and B. abortus for more than 60 years (Olsen, 2005). Current vaccines are effective in preventing abortion and transmission of brucellosis, but poor at preventing infection. As Brucella infections occur mainly through mucosal surfaces, the development of mucosal administered vaccines could be radical for the control of brucellosis (Arenas et al., 2000). This work aimed to Afford protection effect of oral Rev.1 vaccine against challenge infection with B. melitensis $16 \mathrm{M} .\left(1 \times 10^{5} \mathrm{CFU}\right)$ in mice against challenge with $16 \mathrm{M}$. Vaccination with oral flagellar protein $\mathrm{H} 7$ to induce protection against B.melitensis $16 \mathrm{M}$ infection in mice against challenge with 16M. Detect the protection level of combined reduced dose of Rev.1 vaccine and flagellar protein orally against challenge with $16 \mathrm{M}$. Compare between the different type of vaccination to $\mathrm{S} / \mathrm{C}$ full dose of Rev.1 vaccine against challenge with $16 \mathrm{M}$. Detect the spleen bacterial count in each group. Western blot for sonicated $\mathrm{B}$. melitensis Rev.1 and 16M against hyper immune serum of flagellin $\left(\mathrm{H}_{7}\right)$.

\section{MATERIALS AND METHODS}

\subsection{Experimental animals}

Males white BALB C mice: Total number of (200) BALB C Mice of about (30) grams were used. The mice were fed a balanced commercial ration. All animals provided were proved to be Brucella free by serotesting (Rose Bengal Test, Buffered Acidified Plate Antigen Test). These animals were divided into (5) groups according to the following table (1).

\subsection{Experimental Design:}

1. Types of different immune potentiation (adjuvants):

Flagellin, local prepared from virulent strain of E. coli O157:H7. Dosage: $0.2 \mathrm{ml}$ of flagellin contains $40 \mu \mathrm{g}$ of flagellin. (McNeily et al., 2008).

\subsubsection{Brucella strains:}

\subsubsection{Brucella melitensis Rev.1:}

A vaccinal strain was kindly obtained from seed strain (obtained from National Veterinary Services Laboratories "NVSL", 1800 Dayton Avenue, Ames, Iowa, 50010, USA).

\subsubsection{Brucella melitensis strain 16M:}

It was supplied by USDA, USA, National Veterinary Services Laboratories "NVSL", Ames, Iowa, 50010. Strains (3.1.2.1, 3.1.2.2., 3.1.2.3) were reconstituted in 10 $\mathrm{ml}$ diluent (0.75 $\mathrm{M} \mathrm{NaCl}, \mathrm{pH} 6.4)$.

\subsubsection{Brucella abortus strain RB51:}

Brucella abortus strain RB51 a vaccinal strain, is kindly provided by private cattle farm, lyophilized vaccine vials of 5 doses, each and the dose of $\left(3.4 \times 10^{10} \mathrm{CFU}\right)$, lyophilized vaccine, serial No. 1472, Professional Biological Company, 4950 York St., Denver, Colorado 8021. USA. The vaccine vial was reconstituted in $10 \mathrm{ml}$ diluent (0.15M NaCl, $\mathrm{pH} 6.4$ ).

\subsection{E. coli O157:H7 (EHEC):}

Strains was tested and confirmed by standard technique. The strain was kindly provided by serological Unit of Animal Health Research Institute, Dokki, and Giza, Egypt.

Preparation of H7 flagellin: H7 flagellin was prepared and examined by SDS-PAGE as described in (He and Keel, 1994). Purified flagellin $\mathrm{H} 7$ protein was determined.

Western Blot Procedure: (Towbin et al., 1979). Western blot allows to determine the molecular weight of a protein and to measure relative amounts of the protein present to different samples in lanes.

\subsection{Brucella antigens:}

\subsubsection{Rose Bengal Antigen:}

Prepared in VSVRI, Abbasia, Cairo accpording to Alton et al. (1988).

\subsubsection{Tube Agglutination Antigen (B. abortus):}

Prepared in VSVRI, Abbasia, Cairo, according to Alton et al. (1988). 


\subsection{Brucella vaccine:}

Brucella melitensis Rev.1 vaccine prepared in VSVRI, Abbasia, Cairo, according to Alton et al. (1988).

\subsection{RB51 Brucellin:}

Professional Biological Company, 4950 York Street, Denver, Colorado 80216. Evaluation of cell mediated immune response: Brucellin test (Delayed Type Hyper Sensitivity test) in mice. Method of Brucellin test (Delayed Type Hypersensitivity test): (According to Araya et al., 1989); A total of 30 white mice (BALB C mice) was sensitized by an oral local prepared Rev.1 mixed with flagellin gave 3 doses interval 1 week fifteen days after vaccination, the left and right flanks of mice were cleanly shaved and each mouse was injected I/D with $0.1 \mathrm{ml}$ RB51 brucellin, each diluted $1: 10,1: 20,1: 100$. The diameter of the erythema zone at the injection of Brucellin was measured with caliper $24 \mathrm{hr}$. and $48 \mathrm{hr}$. after the I/D injection.

\subsubsection{Culture media:}

Tryptone soya agar: Tryptone soya agar medium with bovine serum 5-10 \% prepared according to method of Alton et al. (1988).

\subsection{Potency test for (G1-G5):}

Challenged mice 3 weeks after vaccination intraperitoneally with $5 \times 10^{8} \mathrm{CFU}$ of (B. melitensis $16 \mathrm{M}$ ) or (E.coli). All mice in each group were slaughtered 3 weeks after challenge. According to OIE (2000).

\section{RESULTS}

\subsection{Protection assay}

To analyze the vaccines efficacy of different groups mice against virulent B.melitensis $16 \mathrm{M}$ oral challenge infections, or in vivo protection study in mice was performed. In this experiment, protection was defined as significant reductions in the mice receive the different type's vaccines.
The vaccine efficacy was calculated according to OIE (2000) as response and protection mice $<2.5$, standard deviation calculated each group of mice is lower mean 0.8 .

Table (3) and Fig (1) shows that mice G3 immunized with Oral reduce dose of Rev.1 vaccine and flagellin gave 3 succive doses at I week interval gave lower of number of Brucella count mean (237.94 CFU / spleen) and protection $(\mathrm{P}) 1.99 \neq 0.106$ against B.melitensis $16 \mathrm{M}$ challenge.

\subsection{Result of cell mediated immune response of mice judged by skin delayed hyper sensitivity test (SDHT):}

Table (4) FIG (2) Showed diameter (mm) of four erythema zones in mice vaccinated orally with three reduced doses Rev.1 $\left(2 \times 10^{7} \mathrm{CFU}\right)$ (about 1-week interval) mixed with flagellin and inoculated I/D with RB51 Brucellin. Dose of RB51 Brucellin: $0.1 \mathrm{ml}$. Six adult mice were sensitized by three orally reduced doses of Rev.1 vaccine (1$2 \times 107$ CFU) about 1-week interval. Both sides of abdomen of vaccinated mice cleanly shaved of four parts and each mouse injected I/D with $0.1 \mathrm{ml}$ of Rb51 brucellin diluted 1:10, 1:20, 1:100, saline solution. Erythema zone measured after $48 \mathrm{hr}$. /D injection of brucellin. The maximum reaction was recorded at $24 \mathrm{hr}$., while at $48 \mathrm{hr}$. decreased in intensity of response was observed. In this study, mice immunized with purified $\mathrm{H} 7$ and developed a high immune serum against flagellin. Western blotting with anti-flagellin to detect and calculate molecular mass $(\mathrm{KDa})$ of the flagellin proteins in sonicated B. melitensis $16 \mathrm{M}$ and Rev.1 as in photo.

\section{DISCUSSION}

Brucella is intracellular pathogens, these bacteria exquisitely well adapted to survival and replication inside eukaryotic cells which is one of the basis for the well-known but still poorly explained chronically 
Table (1): Number of animals in groups of BALB C- Mice and type of injected materials

\begin{tabular}{|c|c|c|c|}
\hline $\begin{array}{l}\text { Mice } \\
\text { groups }\end{array}$ & $\begin{array}{l}\text { No. of } \\
\text { animals }\end{array}$ & Type of injected materials & $\begin{array}{l}\text { Route of } \\
\text { injection }\end{array}$ \\
\hline Group (1) & 40 & Full dose of local prepared Rev.1 vaccine & $\mathrm{S} / \mathrm{C}$ \\
\hline Group (2) & 40 & Flagellin only & orally \\
\hline Group (3) & 40 & $\begin{array}{l}\text { Reduced dose of local prepared Rev.1 vaccine } \\
\qquad+ \text { Flagellin }\end{array}$ & orally \\
\hline Group (4) & 40 & Full dose of local prepared Rev.1 vaccine + flagellin & $\mathrm{S} / \mathrm{C}$ \\
\hline Group (5) & 40 & Control group injected with PBS & orally \\
\hline
\end{tabular}

Table (2): Groups of experimental animals (BALB C-mice)

\begin{tabular}{|c|c|c|c|c|c|}
\hline & Group (1) & Group (2) & Group (3) & Group (4) & Group (5) \\
\hline $\begin{array}{l}\text { Type of } \\
\text { injected } \\
\text { materials }\end{array}$ & $\begin{array}{l}\text { Full dose of } \\
\text { Local prepared } \\
\text { Rev.1 vaccine }\end{array}$ & Flagellin only & $\begin{array}{l}\text { Reduced dose of } \\
\text { local prepared of } \\
\text { Rev. } 1 \\
\text { vaccine+flagellin }\end{array}$ & $\begin{array}{c}\text { Full dose of Local } \\
\text { prepared Rev.1 } \\
\text { vaccine + flagellin. }\end{array}$ & $\begin{array}{c}\text { PBS } \\
\text { Phosphate } \\
\text { buffer saline }\end{array}$ \\
\hline $\begin{array}{l}\text { No. of } \\
\text { dose }\end{array}$ & Only one dose & $\begin{array}{l}\text { 3succesive } \\
\text { doses } \\
\text { 1weeks }\end{array}$ & 3 succesive doses & Only one dose & $\begin{array}{l}\text { Only one } \\
\text { dose }\end{array}$ \\
\hline Time & & $\begin{array}{c}\text { intervals } \\
\text { between } 1^{\text {st }}, \\
2^{\text {nd }} \text { and } 3^{\text {rd }} \\
\text { dose }\end{array}$ & $\begin{array}{l}\text { 1weeks intervals } \\
\text { between 1st, 2nd } \\
\text { and 3rd dose }\end{array}$ & & \\
\hline $\begin{array}{l}\text { Dosage of } \\
\text { each } \\
\text { materials }\end{array}$ & $\begin{array}{l}\text { Does of full dose } \\
\text { of Rev.1: } \\
\left(1-2 \times 10^{8} \mathrm{CFU}\right)\end{array}$ & $\begin{array}{l}\text { Dose of } \\
\text { flagellin: } \\
40 \mu \mathrm{g}(\text { this is } \\
\text { repeated } 3 \\
\text { times) for } 3 \\
\text { successive } \\
\text { weeks }\end{array}$ & $\begin{array}{c}\text { Dose of } \\
\text { flagellin: } 40 \mu \mathrm{g} \text { it is } \\
\text { repeated for } 3 \\
\text { successive weeks } \\
\text { and mixed together. } \\
\text { Dose of reduced } \\
\text { dose of Rev.1: } \\
\left(1-2 \times 10^{6} \mathrm{CFU}\right)\end{array}$ & $\begin{array}{c}\text { Dose of local } \\
\text { prepared Rev.1 } \\
\text { vaccine: } \\
\text { Full dose of Rev.1 } \\
\text { vaccine } \\
\left(1-2 \times 10^{8} \mathrm{CFU}\right) \\
\text { Dose of flagellin: } \\
120 \mu \mathrm{g} .\end{array}$ & $\begin{array}{c}\text { Infected } \\
\text { dose of } \\
\text { B.melitensis } \\
16 \mathrm{M} \\
(1- \\
\left.2 \times 10^{5} \mathrm{CFU}\right)\end{array}$ \\
\hline $\begin{array}{l}\text { Route of } \\
\text { injection }\end{array}$ & $\mathrm{S} / \mathrm{C}$ & Oral & Oral & $\mathrm{S} / \mathrm{C}$ & Oral \\
\hline $\begin{array}{l}\text { Challenge } \\
\text { test }\end{array}$ & $\begin{array}{c}\text { Give } 10 \text { mice } \\
\text { were } \\
\text { experimentally } \\
\text { infected with } B \text {. } \\
\text { melitensis } 16 \mathrm{M} \\
\left(1-2 \times 10^{5} \mathrm{CFU}\right) \\
\mathrm{I} / \mathrm{P}\end{array}$ & $\begin{array}{r}\text { Time of cha } \\
\text { After } 3 \text { wee } \\
\text { va } \\
\text { Give } 10 \text { mice } \\
\text { experimen } \\
\text { B.melitensis }\end{array}$ & $\begin{array}{l}\text { enge for group } 2,3 \text { : } \\
\text { s from last dose of } \\
\text { cination. } \\
\text { om each group were } \\
\text { lly infected with } \\
6 \mathrm{M}\left(1-2 \times 10^{5} \mathrm{CFU}\right) \\
\mathrm{I} / \mathrm{P} \text {. }\end{array}$ & $\begin{array}{c}\text { After } 3 \text { weeks from } \\
\text { vaccination Give } 10 \\
\text { mice were } \\
\text { experimentally } \\
\text { infected with } \\
\text { B.melitensis } 16 \mathrm{M} \\
\left(\left(1-2 \times 10^{5} \mathrm{CFU}\right.\right. \\
\mathrm{I} / \mathrm{P} .\end{array}$ & \\
\hline $\begin{array}{l}\text { Slaughter } \\
\text { of animals }\end{array}$ & \multicolumn{5}{|c|}{$\begin{array}{c}\text { Animals were slaughter at the } 3 \text { weeks post challenge and the spleen were removed aseptically } \\
\text { and weighted and then homogenized in sterile PBS. }\end{array}$} \\
\hline
\end{tabular}


Table (3) Results of potency test of different mice groups.

\begin{tabular}{|c|c|c|c|c|c|c|c|c|c|c|c|c|}
\hline \multirow{2}{*}{$\begin{array}{l}\text { serial } \\
\text { No. }\end{array}$} & \multicolumn{3}{|c|}{ Group (1) } & \multicolumn{3}{|c|}{ Group (2) } & \multicolumn{3}{|c|}{ Group (3) } & \multicolumn{3}{|c|}{ Group (4) } \\
\hline & $\begin{array}{l}\text { Colonie } \\
\text { s/spleen }\end{array}$ & $\begin{array}{c}\log \\
\mathrm{Y}\end{array}$ & $\begin{array}{c}\text { Prot } \\
\text { ectio } \\
\text { n }\end{array}$ & $\begin{array}{l}\text { Colonie } \\
\text { s/spleen }\end{array}$ & $\log Y$ & $\begin{array}{l}\text { Pro } \\
\text { tect } \\
\text { ion }\end{array}$ & $\begin{array}{l}\text { Colonie } \\
\text { s/spleen }\end{array}$ & $\begin{array}{c}\log \\
\mathrm{Y}\end{array}$ & $\begin{array}{c}\text { Prot } \\
\text { ectio } \\
n\end{array}$ & $\begin{array}{l}\text { Colonie } \\
\text { S/spleen }\end{array}$ & $\begin{array}{c}\log \\
\mathrm{Y}\end{array}$ & $\begin{array}{c}\text { Prot } \\
\text { ecti } \\
\text { on }\end{array}$ \\
\hline 1 & 350 & 2.138 & $\mathrm{P}$ & 1022 & 2.53 & $\mathrm{NP}$ & 307.5 & 2.09 & $P$ & 200 & 1.93 & $\mathrm{P}$ \\
\hline 2 & 175 & 1.892 & $\mathrm{P}$ & 276 & 2.05 & $\mathrm{P}$ & 212.5 & 1.96 & $\mathrm{P}$ & 287.5 & 2.06 & $\mathrm{P}$ \\
\hline 3 & 830.6 & 2.45 & $\mathrm{P}$ & 1048.2 & 2.5 & NP & 195 & 1.93 & $\mathrm{P}$ & 835 & 2.456 & $\mathrm{P}$ \\
\hline 4 & 831.8 & 2.454 & $\mathrm{P}$ & 1560.1 & 2.7 & NP & 367.5 & 2.156 & $\mathrm{P}$ & 299 & 2.08 & $\mathrm{P}$ \\
\hline 5 & 915.0 & 2.5 & NP & 1694.8 & 2.7 & NP & 286.5 & 2.066 & $\mathrm{P}$ & 170.8 & 1.88 & $\mathrm{P}$ \\
\hline 6 & 1380 & 2.64 & NP & 1348.6 & 2.6 & NP & 141 & 1.816 & $\mathrm{P}$ & 835.6 & 2.456 & $\mathrm{P}$ \\
\hline 7 & 832.3 & 2.454 & $\mathrm{P}$ & 1050.9 & 2.5 & NP & 230.4 & 1.989 & $\mathrm{P}$ & 187 & 1.915 & $\mathrm{P}$ \\
\hline 8 & 646.5 & 2.36 & $\mathrm{P}$ & 686.48 & 2.4 & $\mathrm{P}$ & 250 & 2.018 & $\mathrm{P}$ & 124 & 1.77 & $\mathrm{P}$ \\
\hline 9 & 450.5 & 2.229 & $\mathrm{P}$ & 1211.5 & 2.6 & NP & 150 & 1.838 & $\mathrm{P}$ & 280 & 2.058 & $\mathrm{P}$ \\
\hline 10 & 1395 & 2.647 & NP & 686.48 & 2.4 & $\mathrm{P}$ & 240 & 2.00 & $\mathrm{P}$ & 698.8 & 2.390 & $\mathrm{P}$ \\
\hline Mean & 780.67 & $\begin{array}{l}2.38 \pm \\
0.233\end{array}$ & $\mathrm{P}$ & $\begin{array}{c}1058.50 \\
6\end{array}$ & $\begin{array}{l}2.498 \\
\pm 189\end{array}$ & NP & 237.94 & $\begin{array}{l}1.99 \pm \\
0.106\end{array}$ & $\mathrm{P}$ & 391.77 & $\begin{array}{c}2.10 \\
\pm 249\end{array}$ & $\mathrm{P}$ \\
\hline
\end{tabular}

Table (4): Result of cell mediated immune response of mice judged by skin delayed hyper sensitivity test (SDHT):

\begin{tabular}{lcccc}
\hline $\begin{array}{l}\text { No. of mice } \\
\text { vaccinated }\end{array}$ & $\begin{array}{c}\text { Mice inoculated with diluted } \mathrm{Rb}_{51} \text { brucellin with erythema zone after 24hr. } \\
\text { Saline } \\
\text { solution }\end{array}$ \\
\hline 1 & $1 / 10$ & $1 / 20$ & $1 / 100$ & 0 \\
2 & $15 \mathrm{~mm}$ & $11 \mathrm{~mm}$ & $8 \mathrm{~mm}$ & 0 \\
3 & $15 \mathrm{~mm}$ & $10 \mathrm{~mm}$ & $5 \mathrm{~mm}$ & 0 \\
4 & $15 \mathrm{~mm}$ & $13 \mathrm{~mm}$ & $10 \mathrm{~mm}$ & 0 \\
5 & $10 \mathrm{~mm}$ & $10 \mathrm{~mm}$ & $7 \mathrm{~mm}$ & 0 \\
6 & $10 \mathrm{~mm}$ & $12 \mathrm{~mm}$ & $8 \mathrm{~mm}$ & 0 \\
Mean & $15 \mathrm{~mm}$ & $15 \mathrm{~mm}$ & $10 \mathrm{~mm}$ & 0 \\
\hline
\end{tabular}
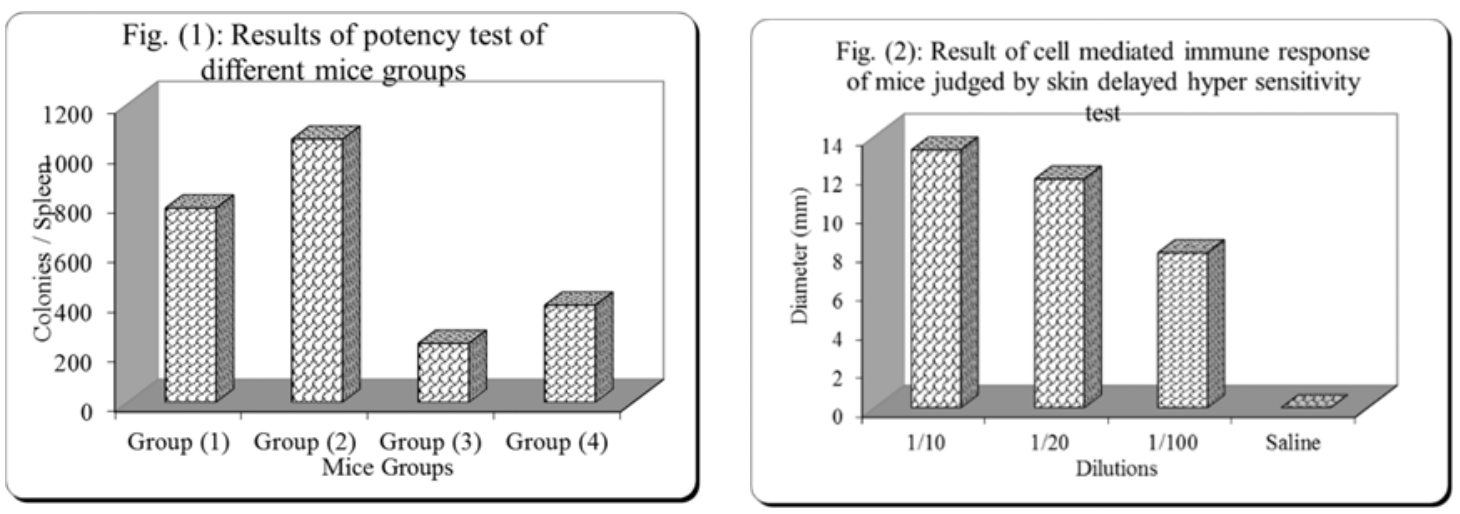
explained chronically of Brucella infection (Ficht,2003) (Lix, et al.,2012) a total of 30 flagellar genes of Brucella abortus were selected for in vitro expression and 15 of these flagellar genes were successfully expressed as this tagged recombinant protein in E.coli ER $25 \mathrm{bb}$, these proteins were purified and used to analyze their $\mathrm{T}$. cell immunity. (Fretin et al., 2005) Brucella melitensis has all the genes needed for and is effectively able to construct a complete flagellar structure. In this study showed that immunization with E.coli flagellin and Rev.1 orally in mice could provide protection against wild strain B.melitensis $16 \mathrm{M}$ infection from these study suggested that flagellin proteins were protective antigens that could produce humoral and cell-mediated in mice. Table (3) agreed wit (Arenas et al., 2009) oral and mucosal vaccination with Rev.1 rapidly cleared from mice within 2 weeks and effectively protected mice upon $\mathrm{I} / \mathrm{P}$ challenge with $\mathrm{B}$. melitensis $16 \mathrm{M}$. The results of potency test of 5 groups of mice vaccinated different type of vaccines and challenged with $\mathrm{B}$. melitensis $10^{5} \mathrm{CFU} \mathrm{I/P}$ are presented in table (3). All groups were challenged after 3 weeks from vaccination G3 of mice gave higher protection log $1.99 \pm 0.106$ and lower mean bacterial counts /spleen. The results of potency test clearly demonstrated that vaccinated with 3 oral reduced dose (Rev.1) $10^{7} \mathrm{CFU}$ ) with flagellin was the best vaccination programme for control of brucellosis. In this study, reported that oral reduce dose table (3) showed high protection when compared to G1 vaccinated with $\mathrm{S} / \mathrm{C}$ full dose Rev.1 ( $\left.10^{8} \mathrm{CFU}\right)$. Oral flagellin in mice G2 display lower protection against challenge by $\mathrm{B}$. melitensis 16M (table 1).

\section{REFERENCES}

Alton, G.G., Jones, L.M., Angus, R.D., Verger, J.M. 1988. Techniques for Brucellosis Laboratory.

Alton, G.G. 1987. Control of Brucella melitensis in sheep and goats -a review. Trop Anim Health Prod 19(2):65-74.

Araya, L.N., laze, P.H., Rowe, G.E., Enift, F.M., Winter, A.J. 1989. Temporal development of protective cell mediated and humoral immunity in $\mathrm{BALB} / \mathrm{C}$ mice infected with $B$. abortus. J. Immunol., 143:33303337.

Arenas, G.N., Staskevich, A.S., Aballay, A., Mayorga, I.S. 2000. Intracellular trafficking of brucella abortus in $\mathrm{J} 774$ macrophages. Infect Immun 68(7):425-563.

Arenas-Gamboa, A.M.1., Ficht, T.A., Davis, D.S., Elzer, P.H., KahlMcDonagh, M., Wong-Gonzalez, A., Rice-Ficht, A.C. 2009. Oral vaccination with microencapsuled strain 19 vaccines confers enhanced protection against Brucella abortus strain 2308 challenge in red deer (Cervus elaphus elaphus). J Wildl Dis. 45(4):1021-9.

Blasco, J.M., 1997. A review of the use of B. melitensis (Rev.1) vaccine in adult sheep and goats. Prev. Vet. Med., 31(3-4):275-283.

Boschiroli, M.L., Foulongne, V.O., Callaghan, D. 2001. Brucellosis :a world wide zoonosis Curr Opin Microbiol 4(1):58-64.

Corbel, M.J. 1997. Brucellosis: An overview. Emerg. Infect. Dis. 3:21321.

Elberg, S.S. 1981. Rev.1 Brucella melitensis vaccine.Part11- 19681980. Vet Bull, 51:67-73.

Ficht, T.A. 2003. Intracellular survival of Brucella defining the link with persistence. Vet Microbiol, 92:213223.

Fretin, D.1., Fauconnier, A., Köhler, S., Halling, S., Léonard, S., Nijskens, C., Ferooz, J., Lestrate, P., Delrue, R.M., Danese, I., Vandenhaute, J., Tibor, A., DeBolle, X., Letesson, J.J. 2005. The sheathed flagellum of Brucella melitensis is involved in persistence 
in a murine model of infection. Cell Microbiol. 7(5):687-698.

He, Y., Keel, B.A. 1994. Biochemical characterization of bovine alphafetoprotein and comparison with human alpha -fetoprotein. Comparative Biochemistry and Physiology part13, 108: 327-336.

Lix, X.u.J., Xie, Y., Qiu, Y., Fu, S., Yuan, X., Ke, Y., Yu, S., Du, X., Cui, M., Chen, Y., Wang, T., Wang, Z., Yu, Y., Huang, K., Huang, L., Peng, G., Chen, Z., Wang, Y. 2012. Vaccination with recombinant flagellar proteins FlgJ and FliN induce protection against Brucella abortus 544 infection in $\mathrm{BALB} / \mathrm{c}$ mice. Vet. Microbiol. 161(1-2): 13744.

McNeilly, T.N., Naylor, S.W., Mahajon, A., Mitchell, M.C., McAteer, S., Deare, D., Smith, D.G.E., Cristopher, Low, J., Gally, D.L., Huntley, J.F. 2008. Escherichia coli O157:H7 colonization in cattle following systemic and mucosal immunization with purified $\mathrm{H} 7$ flagellin. Infect. Immun.76(6):2594-2602.

Marin, C.M., Moreno, E., Moriyon, I., Diaz, R., Blasco, J. M., 1999. Performance of competitive and indirect ELISA, gel immune-precipitation with native hapten polysaccharide and standard serological tests in diagnosis of sheep brucellosis. Clin. Diag. Lab. Immunol., 6(2):269-272.

OIE, 2000. Manual standards of diagnostic tests and vaccines for list $\mathrm{A}$ and $\mathrm{B}$ of mammals, bird and bee.

Olsen, S.C., Stoffregen, W.S. 2005. Essential role of vaccines in brucellosis control and eradication programs for livestock.

Radostitis, O., Gay, S., Constable, P., 2007. Veterinary Medicine 10th ed. O. Radostitis, ed., Billiere Tindal.

Refai, M. 2002. Incidence and control of brucellosis in the Near East region. Vet. Microbiol. 90:81-110.

Scharp, D.W., Alkhalaf, S.A., Al-Muhanna, M.W., Cheema, R.A., Godona, W., 1999. Use of mass vaccination with a reduced dose of Rev.1 vaccine for Brucella melitensis control in a population of small ruminants. Trop. Anim. HIth. Prod., 31(3):135-141.

Towbin, A., Staahelin, J.J.J., Gordon, J. 1979. Electrophoretic transfer of proteins from polyacrylamide gels to nitrocellulose aheets procedure and some applications proceedings of the National Academy of sciences USA 76(9):4350-54.

Zvizdic, S., Cengic, D., Bratic, M., Mehanic, S., Pinjo, F., Hamzic, S. 2006. Brucella melitensis review of the human infection case.Bosn $\mathrm{J}$ Basic Med Sci, 6(1):15-8. 